\title{
Editorial \\ Food Waste: Treatments, Environmental Impacts, Current and Potential Uses
}

\author{
Vita Di Stefano ${ }^{1, *(\mathbb{D})}$, Alessandra Durazzo ${ }^{2, *} \mathbb{C}$ and Massimo Lucarini ${ }^{2, *}$ \\ 1 Department of Biological, Chemical and Pharmaceutical Sciences and Technologies (STEBICEF), \\ 90128 Palermo, Italy \\ 2 CREA-Research Centre for Food and Nutrition, Via Ardeatina 546, 00178 Rome, Italy \\ * Correspondence: vita.distefano@unipa.it (V.D.S.); alessandra.durazzo@crea.gov.it (A.D.); \\ massimo.lucarini@crea.gov.it (M.L.)
}

Citation: Di Stefano, V.; Durazzo, A.; Lucarini, M. Food Waste: Treatments, Environmental Impacts, Current and Potential Uses. Sustainability 2022, 14, 234. https://doi.org/10.3390/ su14010234

Received: 14 December 2021 Accepted: 20 December 2021 Published: 27 December 2021

Publisher's Note: MDPI stays neutral with regard to jurisdictional claims in published maps and institutional affiliations.

Copyright: (C) 2021 by the authors. Licensee MDPI, Basel, Switzerland. This article is an open access article distributed under the terms and conditions of the Creative Commons Attribution (CC BY) license (https:// creativecommons.org/licenses/by/ $4.0 /)$.

\section{Introduction}

Food waste is a major environmental and social concern, and its impact will most likely increase as the population grows. The Food and Agriculture Organization of the United Nations (FAO) has predicted that by 2050, food production will increase by more than $70 \%$ to feed 9.1 billion people [1].

Impactful images are related to waste generated at the crop level, where every day large quantities of fruit and vegetables are discarded for not meeting the sales standard, in terms of size and general appearance. In industrialized countries, over $50 \%$ of the production of roots and tubers and about $46 \%$ of fruit and vegetable production is lost or wasted, considering the edible parts of food products produced for human consumption.

Moreover, in the agri-food chain during the processing and transformation of food products, significant quantities of by-products and waste are generated, the disposal of which produces negative environmental and economic impacts. The adoption of an industrial symbiosis approach to transfer and share resources between different industries reflects recent European strategies on decoupling economic growth from environmental impacts.

Therefore, it is necessary to study sustainable food systems that guarantee nutrition, health, and food safety, with the intention of not compromising the economic, social, and environmental circumstances of future generations.

To achieve this sustainability, we need to think about multidisciplinary integrated approaches from farm to house.

One of the main challenges of the sustainable management of food industry waste according to the "zero waste" model is the application of the circular management strategy with the inevitable development of innovative waste transformation techniques.

Agro-industrial supply chains provide numerous high-value-added by-products, and the exploitation of green extraction techniques is gaining particular interest with regard to the recovery of bioactive substances from waste and by-products of the food industry with the aim of providing faster, more efficient, safer, and more sustainable alternatives to conventional extractions.

Understanding how these natural compounds interact with biological targets opens their use to pharmaceutical interest, but also to those engaged in "food science", for example in the production of functional foods, food supplements, food preservatives, cosmetics, etc. [2-4].

The Special Issue, entitled "Food Waste: Treatments, Environmental Impacts, Current and Potential Uses", will focus on original scientific reviews and papers relating to all types of food production, waste/by-product generation and their use, value products added (bulk chemicals, fine chemicals, high-value compounds: enzymes, proteins, polyphenols, etc.), new technical and technological solutions, environmental compatibility, life cycle analysis, and the legislation without which there is no implementation. 
Author Contributions: V.D.S., A.D. and M.L. have made a substantial, direct, and intellectual contribution to the work, and approved it for publication. V.D.S., A.D. and M.L. All authors have read and agreed to the published version of the manuscript.

Funding: This research received no external funding.

Conflicts of Interest: The authors declare no conflict of interest.

\section{References}

1. FAO. Global Food Losses and Food Waste-Extent, Causes and Prevention; United Nations: Rome, Italy, 2011; pp. 1-37.

2. Durazzo, A.; Lucarini, M.; Santini, A. Nutraceuticals in Human Health. Foods 2020, 9, 370. [CrossRef]

3. Guarrasi, V.; Rappa, G.C.; Costa, M.A.; Librizzi, F.; Raimondo, M.; Di Stefano, V.; Germanà, M.A.; Vilasi, S. Valorization of Apple Peels through the Study of the Effects on the Amyloid Aggregation Process of k-Casein. Molecules 2021, 26, 2371. [CrossRef]

4. Melilli, M.G.; Di Stefano, V.; Sciacca, F.; Pagliaro, A.; Bognanni, R.; Scandurra, S.; Virzì, N.; Gentile, C.; Palumbo, M. Improvement of Fatty Acid Profile in Durum Wheat Breads Supplemented with Portulaca oleracea L. Quality Traits of Purslane-Fortified Bread. Foods 2020, 9, 764. [CrossRef] 